\title{
BRIEF COMMUNICATIONS
}

POLYSACCHARIDES OF Eremurus.

XXI. A GALACTURONAN FROM THE PECTIN SUBSTANCES OF THE

\section{LEAVES OF Eremurus lactiflorus}

N. P. Yuldasheva and D. A. Rakhimov

UDC 547.917

Continuing investigations into the pectin substances (PSs) of plants of the genus Eremurus [1], we have studied the PSs of the leaves of E. lactiflorus 0 . Fedtsch.

The partial acid hydrolysis of the PSs (2 $\mathrm{N} \mathrm{H}_{2} \mathrm{SO}_{4}, 98^{\circ} \mathrm{C}, 4 \mathrm{~h}$ ) gave a polysaccharide (a galacturonan with a yield of $25 \%),[\alpha]_{\mathrm{D}}^{20}+240^{\circ}(\mathrm{c} 0.2 ; 0.1 \mathrm{~N}$. NaOH). D-Galacturonic acid was detected in a hydrolysate of the galacturonan by PC (butan-1-ol-pyridine-water. (6:4:3) system with aniline hydrogen phthalate as the chromogenic agent).

To prove the position of the bonds between the galacturonic residues the galacturan was subjected to periodate/nitric acid oxidation [2]. Oxalic and tartaric acids were detected in the products of its oxidation by PC (butan-1-o1-acetic acid-water (4:1:5) system with aniline/glucose as the chromogenic agent). The formation of tartaric acid showed that $\alpha$-diol groupings had undergone oxidation. This is possible when there is a $1 \rightarrow 4$ bond between galacturonic acid residues.

The methylation of the galacturonan was difficult, and it was therefore esterified with diazomethane [3] and reduced with tetrahydroborate, which gave a galactan in a hydrolysate of which galactose was detected. The galactan was methylated by Hakomori's method [4], and methylation was completed by Purdie's method [6]. A galactan permethylate was obtained with $[\alpha]_{\mathrm{D}}^{20}+19^{\circ}\left(\mathrm{c} 1.5 ; \mathrm{CHCl}_{3}\right)$ the IR spectrum of which lacked the absorption band of hydroxy groups.

The products of the complete acid hydrolysis of the permethylate were shown by TLC (benzene-acetone ( $1: 1$ ) system with aniline hydrogen phthalate as chromogenic agent) to contain 2,3,6-tri-0-methy1-D-galactose and 2,3,4,6-tetra-0-methyl-D-galactose by a comparison with markers.

To confirm the results obtained, the galacturonan was investigated by ${ }^{13} \mathrm{C}$ NMR spectroscopy. The ${ }^{13} \mathrm{C}$ NMR spectrum of the galacturonan had the following signals, given with their chemical shifts: $\mathrm{C}-1(100.15 \mathrm{ppm}), \mathrm{C}-2(69.7 \mathrm{ppm}), \mathrm{C}-3(70.4 \mathrm{ppm}), \mathrm{C}-4$ (79.2 ppm), C-5 $(72.7 \mathrm{ppm})$, and $\mathrm{C}-6(176 \mathrm{ppm})$. These values of the signals correspond to those given in the literature [6] and show that the galacturonan consisted of a chain of $\alpha-1 \rightarrow 4-1$ inked D-galacturonic acid residues.

Thus, the galacturonan is a linear polymer consisting of D-galacturonic acid residues linked with one another by $\alpha-1 \rightarrow 4-$ glycosidic bonds.

\section{LITERATURE CITED}

1. N. P. Yuldasheva, D. A. Rakhimov, and E. S. Kondratenko, Khim. Prir. Soedin., 114 (1985).

2. A. G. Gorin, Khim. Prir. Soedin., 80 (1967).

3. G. 0. Aspinall and A. Ganas-Rodriguez, J. Chem. Soc., 4020 (1958).

4. S. Hakomori, J. Biochem. (Tokyo), 55, 205 (1964).

5. Methods in Carbohydrate Chemistry [in Russian] [Russian translation of Volumes I-V of Methods in Carbohydrate Chemistry (ed. R. L. Whistler), Academic Press, New York (1962-1965)], Moscow (1967), p. 463.

6. G. Chambat and J.-P. Joseleau, Carbohydr. Res., 85, C10-C12 (1980).

Institute of the Chemistry of Plant Substances of the Uzbek Academy of Sciences, Tashkent. Translated from Khimiya Prirodnykh Soedinenii, No. 5, p. 635, September-October, 1986. Original article submitted April 30, 1986. 